\title{
Education Policy in Periods of Modernization: A Comparison of Turkey and South Korea
}

\author{
Sue-Yeon Song \\ New York University, New York, USA
}

\begin{abstract}
This paper compares education policies and outcomes during the periods of modernization in Turkey and South Korea. Though the modernization era in these countries occurred at different periods of time-in Turkey from 1923 to 1938 and in South Korea from 1963 to 1979—both were implemented under the centralized authoritarian leadership. Controversial leaders, Mustafa Kemal Atatürk in Turkey and Chung-hee Park in South Korea, each initiated that drastic reforms aimed at building a modern nation state, and new education policies acted as an important means for both to achieve their modernization objectives. However, despite a shared goal of modernizing society, the process and contents of education policy were strikingly different in Turkey and South Korea, and the outcomes also differed sharply. This paper argues that the religious context of Turkish society, and the conflict between secularism and Islam in particular, constitutes a major reason for slower progress in economic growth and development there compared to Korea.
\end{abstract}

Keywords: education policy, modernization era, Turkish educational reform, Korean educational reform, comparative analysis

\section{Introduction}

This paper presents a comparative analysis of education policy during the periods of modernization in Turkey and South Korea. Although the two countries share some unique similarities, they followed quite distinct paths to economic development and modernization. In the 1950s, Turkey stood out as an auspicious and fast-growing economy, far superior to Korea in development terms over the first half of the 20th century (Yilmaz, 2002). Their relative standing changed notably, however, after Korea launched a modernization plan within the framework of President Chung-hee Park's new development policy in the early 1960s. According to recent statistics, South Korea has achieved some of the world's leading outcomes not only in terms of economic performance, but also in educational improvement. For example, by 2007, tertiary education entry rates as a percentage of the population stood at $29 \%$ in Turkey and as high as $61 \%$ in South Korea, according to the Organization for Economic Co-operation and Development (OECD) Factbook of 2010. The primary school enrollment completion rate in Turkey reached 87 (75th of 148), whereas South Korea's surpassed all other countries at 101 (1st of 148).

Conventional wisdom suggests that education is one of the major driving forces of economic growth. For this reason, in many developing states, education reform constitutes a major political initiative in pursuit of a

Sue-Yeon Song, Ph.D. candidate, Department of Administration, Leadership, and Technology, New York University. 
modernized nation-state. The modernization processes in Turkey and South Korea were no exception. The two countries are similar in historical context, both having experienced a critical period of reform toward modernization under an authoritarian regime. As Huntington (1968) stressed, "The sequences in which many countries have tackled the problems of modernization have been the products of accident and history,” but in the cases of both Turkey and South Korea, the modernization project was consciously planned.

Based on the similar regime contexts in which their modernization efforts began, this paper compares education reform in Turkey under Mustafa Kemal Atatürk from 1923 to 1938 and Korea under President Chung-hee Park from 1963 to 1979. The analysis focuses on the process and outcomes, as well as the major influences that the reforms have brought to the development of each country.

\section{The Modernization Eras of Turkey and South Korea}

\section{The Modernization Era of Turkey under Mustafa Kemal Atatürk}

Turkey under the leadership of Atatürkem barked upon a rapid and thorough effort at modernization beginning with the establishment of the Republic of Turkey in 1923 (Szyliowicz, 1969). The foundation for modernization was built on the long and prestigious history of the Ottoman Empire, along with Turkey's opening to the West. With central authority in the hands of Atatürk, the reform aimed to bring about rapid changes in the socio-economic structure of the country in order to build a modern nation-state. This interest in building a new modern state was not simply an administrative replacement for the failed Ottoman Empire. It can be viewed instead as explicitly shaping a new national identity, in which a new vision of "Turkishness" was defined through the nature of the state (Cooper, 2002). Atatürk restructured the existing system and created modern structures, introducing six basic principles to the Republic of Turkey: nationalism, populism, republicanism, revolutionism, secularism, and statism. These six fundamental elements of the ideology further contributed to the concept of "Kemalism," an ideology which grew out of the Turkish war of independence and promoted whole sale social and cultural reform during the Atatürk period (Kili, 1980). In other words, "Kemalism" became the essential pillar of Atatürk reform.

The crucial texture of Turkish society was the dominant status of Islam. Thus, the most sweeping reforms had to take place in the religious sector, in large measure due to its powerful role in dictating and regulating the everyday life of Turkish citizens through Islamic and local cultural symbols (Pak, 2004).

The separation of state and religion, the replacement of Islamic law by a civil code and a penal law following European models, the introduction of the Western alphabet, the establishment of civil rights corresponding to Western democracies, the introduction of equal rights for women, and other far reaching reforms all contributed to Atatürk's social and cultural vision for the modernization of Turkey (OECD, 1989). Through these efforts, the Republic of Turkey entered a new era of modernization and became a new modern entity.

\section{The Modernization Era of South Korea under Chung-hee Park}

In South Korea, the modernization era started when General Chung-hee Park took power by coup d'état in 1961. Having seized power and become President of South Korea for 16 years until his assassination, Park offers a plausible comparison to Mustafa Kemal Atatürk in Turkey. Park remained a controversial figure in the history of South Korea because of his contributions to both economic development and political repression, but even his critics acknowledge the successful transformation of Korea from economic backwardness to a fast-growing economy during the Park era. 
Under President Park's leadership from 1961 to 1979, Korea achieved significant progress and became one of the few developing countries to break out of low-income status, and to improve markedly in terms of social development, in such a short period of time. The first priority of Park's plan was to follow the developmental state model for agricultural countries, as South Korea was, in order to escape from the colonial past and to promote a shift toward a modern state. The developmental strategy put an emphasis on the three focal points: (a) implementation of industrial policy through economic planning; (b) rigorous promotion of rural village movement; and (c) bureaucratic control over the social and economic reform process. The author briefly reviews the first and second of these points.

It is notable that the military government introduced industrial policy under the name of a "Five Year Economic Development Plan.” Industrial policy was seriously contrived and implemented by the political leadership throughout the authoritarian period. This is the most conspicuous difference between South Korea and other developing countries that tried to leap forward to an advanced economy, and it distinguishes Korea from Turkey, where various social forces frequently intervened in the government's effort to boost economic development and enhance the modernization process.

The first “Five Year Economic Development Plan” was launched under President Park’s leadership in 1962, eventually transforming into a long-term initiative with the completion of a fourth plan in 1976. In the early stage of development, the developmental strategy aimed at export-oriented industrialization with intensive governmental support, and the policy later shifted to capital-intensive heavy and chemical industries in the 1970s.

During the 1970s, while continuing the drive for industrialization, President Park also emphasized the improvement of the agricultural sector as a part of his developmental strategy. The "Saemaul Undong," also known as the "New Village Movement" was proposed by the government to transform farming villages; its intention was to inspire the people living in rural communities with a modern environment, thus, leading them into a modern mentality. All of these plans including the "Five Year Economic Plans" and the "New Village Movements" were directly aimed at improving the economic development of Korea in order to rapidly reach the status of a "New Industrial Nation."

Economic indicators suggest that President Park's modernization plan was a resounding success in development terms. For example, in 1962 South Korea’s exports were a mere $\$ 55$ million; by 1978 they had reached $\$ 12.4$ billion. During the same period, Gross Domestic Product (GDP) per capita rose rapidly from $\$ 87$ to $\$ 1,242$ (Kamiya, 1980).

\section{Education Policy in the Modernization Era}

\section{Turkish Educational Reform}

During the modernization periods of many countries, education has served as an important tool both for acclimating people to social change and for bringing about a transformation in society (Nohl et al., 2008). The Turkish case was no exception; the founding of the Republic of Turkey was the starting point for radical changes in the education system. As the radical shift toward a secular society in the form of modernization efforts took place within a short period of time, dissenting voices and backlash complicated and intensified Turkey's identity crisis (Pak, 2004). On the one side, Islamists were opposed to the introduction of Western norms, wishing instead to maintain the traditional system as well as the Islamic influences. On the other side, however, Kamalist reformists envisioned a clear path from tradition to modernity through the belief that modernization was required to overcome and eradicate the traditional aspects of the society (Kinzer, 2001). 
Islamic religion interests and modernization efforts collided, so seriously across Turkey that Kemalism was faced with various challenges and setbacks from diverse social and religious groups. In short, reform advocates found it exceedingly difficult to construct a modern and westernized identity in such a deeply Islamic religious society (Keyman \& Koyuncu, 2005). This helps to explain why educational reform was not as successful there compared to South Korea, where a religious barrier was not found in the Confucian cultural tradition.

With modernization in mind, Atatürk adopted a new educational policy on the belief that modern and secular education was the most important, requisite element of modernization. He adopted a conscious policy of reorganizing the entire educational system, expanding it in a systematic and balanced way and harnessing it to national goals (Szyliowicz, 1969). The primary task for Atatürk was then to convince people to believe in the merits of a secular society through a new system of national education (Pak, 2004). His efforts in education reform could be summarized according to the two following points.

First, he restructured public education by ending the dual track education system. The previous system was inherited from the Ottoman Empire and placed heavy emphasis on traditional religious elements as well as on the traditional value system. In such a belief system, disenchantment and secularization were not imaginable. Atatürk thus emphasized an expansion of national education based on a secular curriculum, with a focus on nationalist elements, with the goal of confining or eliminating much of the Islamic belief system from general education (Pak, 2004).

Second, Atatürk placed the entire education system under the supervision and control of the state. In 1923, the Ministry of Education took over the administration and control of all existing religious schools, including their endowments, funds, and other means of support (Pak, 2004). One year later, the "Law of Unification of Instruction" was introduced with a code that "all educational institutions are to be placed under the control of the Ministry of Education.” Under the new law, the government was able to centralize the whole education process and to develop a single curriculum for all school children regardless of regional and religious division. The major purpose of this centralization was to place all religious institutions under state control in order to abolish religious education provided by various religious orders.

Through Atatürk's revolution, the Republic of Turkey was able to create a monolithic national identity that fitted the mold of the Kemalist definition of a modern state (Pak, 2004). A critical element of his success came in mobilizing the Turkish modernist elite, which gave the movement internal cohesiveness to an extent that had not been possible before in Turkish history (Kili, 2003).

\section{Korean Educational Reform}

In the modernization era of South Korea, a new education policy served as one of the central features of President Park's “Five Year Economic Development Plan.” The new policy was focused mainly on cultivating human capital that could contribute to the industrialization of the nation. Those reforms were able to capitalize on the educational aspirations of Koreans and achieve remarkable success in a relatively short period of time, largely due to the absence of a religious barrier.

Korea has been a multi-religious country since the late 19th Century, when-with the inflow of Christian and Catholic churches - the government abandoned Confucianism as an official national religion. The historical inflow of Western religion was itself a complicated process, but in short, the Korean government declared an end to the repression of Christians and Catholics under pressure from European nations. Since then, Korea has experienced much greater religious plurality compared to Turkey, which facilitated a shift toward a 
secularized system when modernization efforts increased. Coupled with the mixed religious context has been a historical emphasis on education. Feudal Korea was ruled by a scholarly class for 500 years in the Confucian tradition, which defines the King's power by the existence of ordinary people, but which relies on the scholarly class to define the ruling philosophy, thus giving scholars a premium second position after the King. Confucianism and its religious application thus permit the scholarly class to check and balance the King's rein. To be a scholar was therefore a cherished dream for individuals in feudal Korea, and those aspirations created a legacy of educational importance that has persisted over centuries.

The new education policy that emerged during Park's regime concentrated on the following goals: (a) to increase and equalize secondary education opportunities; and (b) to expand and improve technical and science education (Lee et al., 2010). First, the government initiated an equalization policy in secondary education as a way to expand educational opportunities. This meant removing the entrance examination as a barrier, as primary education became universal, the entrance examination for secondary education was compulsory to pass and severely competitive. Before the introduction of reform, all students had to pass the examinations to enroll in secondary education, which worked as an impediment to the expansion of secondary education. In the late 1960s, the government decided to abolish the entrance examination in order to enhance the enrollment rate for secondary education. Then, in 1974, after a similar policy of equalization was introduced for middle schools, middle school graduates were allocated to senior high school within each school district without entrance examinations (Lee et al., 2010). Instead of applying the same policy to university level education, the government simply lowered the examination requirements, thereby doubling the enrollment in the early 1980s just after the collapse of the Park's regime. Korea was thus able to transform the high educational aspirations of its population in an era of mass education.

Second, vocational and professional education is worth mentioning. President Park attempted to consolidate vocational and technical education at the high school level and to support science and technology education during the 1960s. Demand for secondary education had increased rapidly since the 1950s due to the expansion in elementary education enrollment, and in order to meet that demand, the government tried to accommodate more educational institutions at both the secondary and post-secondary levels, establishing two-year technical colleges and correspondence schools (Kim \& Lee, 2006). As Kim (2010) pointed out that the policy measures which were initiated in order to enhance vocational education during this period could be explained as follows:

(a) specialization of technical high schools; (b) strengthening of experiments and practices in vocational education; (c) initiation of the industry school cooperation system; (d) establishment of certification standards for practical skills texts for vocational high school students; (e) making certification of skill qualifications compulsory; (f) promoting vocational school teacher competency through practical training; (g) increasing scholarships for vocational high school students; and (h) finally providing incentive points on college and university entrance examinations to those vocational school graduates who intended to pursue the same fields of study in colleges and universities that they studied in high school. (p. 338)

By the 1980s, changes in education policy ensured that many more children were attending secondary school, and many more of those were able to attend university by virtue of the doubling of enrollments (Kim \& Lee, 2006). This policy of expanding secondary school enrollment, and of increasing the number of vocational high schools in particular, served as an essential policy to meet the demands of rapid industrialization. More semi-skilled and skilled workers were required for the heavy and chemical industries, and the educational reforms created a supply of individuals capable of providing those skills. 
As it can be seen, education in the modernization period in Korea was mainly intended to cultivate a labor force that could devote itself to the industrial sector and eventually contribute to the economic development of Korea. In this sense, education was the most important contribution to human capital in the shift toward modernization and industrialization.

\section{Comparative Analysis of Education Policy in the Modernization Periods of Turkey and South Korea}

In the previous section, the modernization periods of Turkey and South Korea were discussed. Those eras were similar in that they were commonly implemented under centralized authoritarian leadership, despite occurring at different time periods. Controversial figures in the history of the two countries, Mustafa Kemal Atatürk and Chung-hee Park, both initiated whole sale reforms aimed at building a modern nation state. New education policies were launched as a central pillar of the reforms. Yet, while the main goal of the reforms in both countries was to establish a modern society, the process and contents of education policy were completely different, and the outcomes were also distinct.

In Turkey, educational reform advocates faced the task of overcoming the prevalent influence of Islamic identity. The principal struggle behind educational reform thus became shifting the national identity from an Islamic background to a modernist ideology (Simsek, 2006). In practical terms, the main objective of education reform under Atatürk was focused on the abolishment of religious education. Even in contemporary Turkey, the issue of education especially has driven a salient rift between secularists and Islamists (Pak, 2004).

Huntington (1968) analyzed the strategy of Kemalist reform as follows:

The sequence in which the problems were tackled was designed to move from those where Kemal had the greatest support to those which might arouse the greatest controversy. First priority had to be given to the definition of national community and the delimitation of the ethnic and territorial boundaries of the state. Once, a relatively homogeneous ethnic community had been established, the next step was to create effective modern political institutions for the exercise of authority. It was then possible for those in control to work through the institutions to impose religious, social, cultural, and legal reforms on society. One traditional forms and customs had been weakened or eliminated; the way was then open for industrialization and economic development. (p. 348)

What Huntington described explains the contrasting results between Turkey and Korea, in terms of the disrupted reform in the former and the remarkable success in the latter. Religion stands out as the strongest factor explaining the contrasting outcome. Turkey's reform of education during the period of modernization was frequently challenged by the Islamic culture and beliefs, whereas Korea's relative tolerance to religious differences, even in the context of a Confucian background, became a factor that eventually allowed for a secular system to take hold. Religious challenges in Turkey against the modernizing policy of education disrupted the continuous and consistent policy reforms, even under the authoritarian regime. Kemalism was regarded as a radical ideology to most Islamic people in Turkey, such that secularization could not go further after the death of Atatürk. Since then, Turkish educational reform has repeatedly swung back and forth according to the religious orientation of political leadership. Thus, the introduction of secular and popular education was frequently delayed and institutional conflicts occurred between various ideological and religious groups.

In contrast, South Korea was able to target its goal directly at economic development from the initial stages of educational reform, due largely to the lack of religious intervention. Authoritarian leadership was strong enough to enforce the modern education system as an amalgamation of the Japanese and American models. The Japanese model constituted the colonial legacy in Korea, while the American model offered a new and competitive approach. The authoritarian government combined the expansion of educational opportunities 
with an emphasis on practical and vocational education in order to meet the increasing demand of industrial complexes. Government funding contributed to the mobilization of younger generations in rural areas to focus on vocational and practical learning. Furthermore, the government of Korea, unlike its counterpart in Turkey, received a boost from the religious tenets of Confucianism in the sense that rural populations treated the educational opportunities found in urban cities as a central goal, thereby reinforcing the emphasis on urban development and industrialization. Not all could join a scholarly or ruling class, those semi-skilled and skills young workers were nevertheless absorbed into factories in industrial complexes. As a result, the educational reforms in Korea provided the human resources necessary for industrialization, which in turn contributed to its economic development.

\section{Conclusion and Discussion}

This paper considered the education policies during the modernization periods of Turkey and South Korea in comparative perspective. Throughout the paper, the author argued that the religious context of Turkish society, and the conflict between secularism and Islam in particular, was a major factor in slowing the progress of economic growth there compared to Korea. It cannot be generalized that Islamic religion generates negative attitudes and values with respect to modernization, but the Turkish case-in which social conflicts between secularists and Islamists disturbed educational reform —-may be supportive of the argument. For instance, there are few democracies in the Islamic region, a detail which Huntington (1993) suggested could indicate that Islamic democracies are a logical contradiction. However, the recent wave of democratization movements in the Islamic world casts some doubt on the strength of that argument. Huntington also argued that Confucianism's central themes run counter to democracy. This argument also turns out to be inadequate, since many Asian countries with Confucian cultural backgrounds have successfully transitioned to democracy. South Korea is a good example. Confucianism, in fact, has become an accelerating element of modernization in the recent era, whereas Islamic culture and religion have in some cases reduced the negative forces against modernization. A similar statement can be applied to education reform in both countries. Turkish educational reform occurred in the period when negative forces against modernization were at a high point just after the liberation that triggered a popular movement toward traditional values and customs. An analogous incident occurred in Korea after liberation but the ideological conflict ended in a civil war. Civil war may be the purification of ideological conflict that is congruent with the religious conflict in Turkey.

As a concluding remark, it may be seen as controversial to contend that religious factors are detrimental to the modernization of educational systems. However, evidence from the Turkish case lends support to a cultural argument, and the success of Korea's education reform, in the absence of strong religious constraints, further reinforces the cultural observation. Obviously, culture is an elusive concept, but the analysis in this paper leads to the tentative statement that, when it comes to historical religious influences on education policy and culture matters.

\section{References}

Cooper, M. (2002). The legacy of Atatürk: Turkish political structures and policy-making. International Affairs, 78(1), $115-128$. Huntington, S. P. (1968). Political order in changing societies. New Haven, C.T.: Yale University Press.

Huntington, S. P. (1993). The third wave: Democratization in the late twentieth century. Norman and London: University of Oklahoma Press.

Kamiya, F. (1980). The Korean peninsula after Park Chung Hee. Asian Survey, 20(7), 744-753. 
Keyman, E. F., \& Koyuncu, B. (2005). Globalization, alternative modernities and the political economy of Turkey. Review of International Political Economy, 12(1), 105-128.

Kili, S. (1980). Kemalism in contemporary Turkey. International Political Science Review, 1(3), 381-404.

Kili, S. (2003). The Atatürk revolution: A paradigm of modernization. Milet Publishing Ltd..

Kim, S., \& Lee, J. (2006). Changing facets of Korean higher education: Market competition and the role of the state. Higher Education, 52(3), 557-587.

Kim, Y. (2010). Education and economic growth in Korea: 1945-1995. In C. Lee, S. Kim, \& D. Adams (Eds.), Sixty years of Korean education (pp. 326-359). Seoul: Seoul National University Press.

Kinzer, S. (2001). Crescent and star: Turkey between two worlds. New York: Farrar, Straus, and Giroux.

Lee, C., Kim, S., \& Adams, D. (Eds.). (2010). Sixty years of Korean education. Seoul: Seoul National University Press.

Nohl, A., Akkoyunly-Wigley, A., \& Wigley, S. (Eds.). (2008). Education in Turkey. Germany: Waxmann Verlag GmbH.

Organization for Economic Co-operation and Development (OECD). (1989). Review of national policies for education: Turkey. Paris: OECD Publishing.

OECD. (2010). OECD Factbook 2010: Economic, environmental and social statistics. Paris: OECD Publishing.

Pak, S. (2004). Cultural politics and vocational religious education: The case of Turkey. Comparative Education, 40(3), $321-341$.

Simsek, H. (2006). Turkey. In J. Forest, \& P. Altbach (Eds.), International handbook of higher education (pp. 1003-1018). New York: Springer.

Szyliowicz, J. (1969). Education and political development in Turkey, Egypt, and Iran. Comparative Education Review, 13(2), 150-166.

Yilmaz, B. (2002). The role of trade strategies for economic development: A comparison of foreign trade between Turkey and South Korea. Russian and East European Finance and Trade, 38(2),59-78. 